\title{
SOSIALISASI PENCEGAHAN KEBAKARAN DI LAHAN GAMBUT DAERAH BERENG BENGKEL KOTA PALANGKA RAYA
}

\author{
NOVRIANTI, NIRWANA PUSPASARI, NOVIYANTHY HANDAYANI, ST. MT. \\ Dosen Prodi Teknik Sipil Universitas Muhammadiyah Palangkaraya
}

\begin{abstract}
ABSTRAK
Gambut adalah jenis tanah yang terbentuk dari akumulasi sisa-sisa tumbuhan yang setengah membusuk, oleh sebab itu, kandungan bahan organiknya tinggi. (Wikipedia, 2016). Kebakaran lahan gambut di provinsi Kalimantan Tengah pada tahun 2015 lalu sangatlah parah apabila dibandingkan dengan tahun-tahun sebelumnya. Hampir semua hutan atau lahan mengalami kebakaran. Kebakaran lahan tidak hanya terjadi didaerah kawasan hutan tetapi juga di dalam kota Palangka Raya itu sendiri. Hal ini selain dipicu karena pembakaran lahan dengan sengaja, juga disebabkan karena faktor alam (pohon-pohon yang mengering), hembusan angin yang kuat, dan juga kelalaian manusia itu sendiri (seperti membuang puntung rokok pada daerah hutan yang kering). Akibat kebakaran lahan hutan yang luas, mengakibatkan terjadinya kabut asap dan menyebabkan polusi udara yang menghambat jalur penerbangan udara dan darat sehingga membuat harga bahan pokok di Palangka Raya beranjak naik. Untuk itulah perlu diadakannya sosialisasi pencegahan kebakaran di lahan gambut kepada masyarakat. Pada sosialisasi ini diberikan informasi kepada masyarakat tentang penyebab kebakaran lahan, cara pencegahan dan penanggulangannya. Berdasarkan hasil sosialisasi tersebut, masyarakat lebih mengerti penyebab kebakaran lahan, cara pencegahan dan cara penanggulangannya, sehingga diharapkan dapat mencegah atau mengurai terjadinya kebakaran lahan ditahun-tahun mendatang.
\end{abstract}

Kata Kunci : Gambut, Lahan, Kebakaran

\section{PENDAHULUAN}

Gambut adalah jenis tanah yang terbentuk dari akumulasi sisa-sisa tumbuhan yang setengah membusuk, oleh sebab itu, kandungan bahan organiknya tinggi. Tanah yang terutama terbentuk di lahan-lahan basah ini disebut dalam bahasa Inggris sebagai peat; dan lahan-lahan bergambut di berbagai belahan dunia dikenal dengan aneka nama seperti bog, moor, muskeg, pocosin, mire, dan lain-lain. Istilah gambut sendiri diserap dari bahasa daerah Banjar. Sebagai bahan organik, gambut dapat dimanfaatkan sebagai sumber energi. Volume gambut di seluruh dunia diperkirakan sejumlah 4 trilyun $\mathrm{m}^{3}$, yang menutupi wilayah sebesar kuranglebih 3 juta $\mathrm{km}^{2}$ atau sekitar $2 \%$ luas daratan di dunia, dan mengandung potensi energi kira-kira 8 miliar terajoule (Wikipedia, 2016).

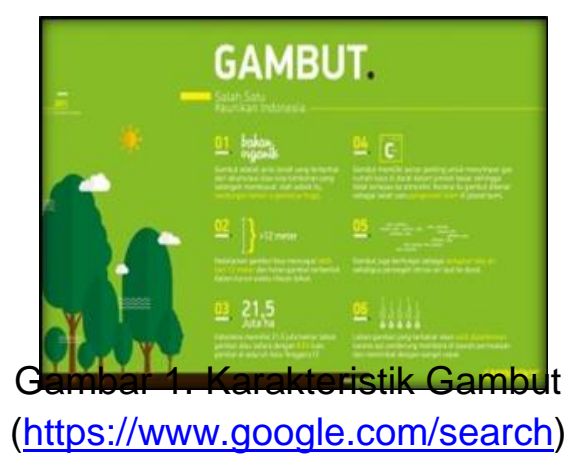


Lahan basah yang memiliki tanah gambut yang berkarbon-rapat ini merupakan rumah bagi berbagai jenis margasatwa yang telah terancam keberadaannya, seperti halnya Orang utan. Akan tetapi, hutan gambut yang sangat kaya ini telah dan sedang mengalami ancaman pembalakan, pembakaran dan pengalihan menjadi lahan pertanian, seperti misalnya menjadi lahan perkebunan kelapa sawit. Hal ini menyebabkan emisi karbondioksida $\left(\mathrm{CO}_{2}\right)$ yang sangat besar dan memusnahkan habitat binatangbinatang langka yang terancam punah. Penelitian Wetlands International Indonesia menunjukan bahwa secara global, lahan gambut menyimpan paling sedikit 550 Gigaton karbon dalam lapisan tanah organiknya. Ini adalah dua kali lipat jumlah karbon yang tersimpan di hutan di seluruh dunia. Penyimpanan karbon oleh lahan gambut ini pada dasarnya membantu mengurangi terjadinya perubahan iklim global. Di Indonesia, lahan gambut mencakup luas 20,6 juta hektar atau sekitar $10,8 \%$ dari luas daratan negara Indonesia (Wetlands International Indonesia, 2009).

Kawasan bergambut di Kalimantan Tengah melingkupi hamparan areal yang cukup luas, yakni diperkirakan mencakup areal seluas 3,472 Juta $\mathrm{Ha}$, atau sekitar $\mathbf{2 1 , 9 8} \%$ dari total luas wilayah Propinsi Kalimantan Tengah yang mencapai 15,798 Juta Ha (http://kalteng.go.id).

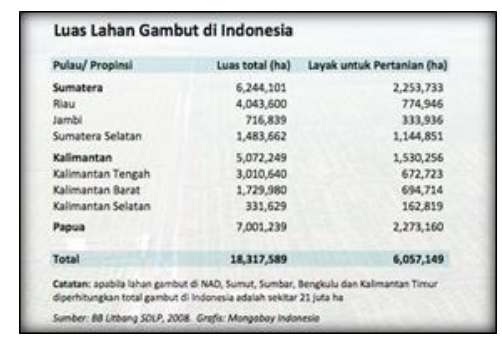

Gambar 2. Luas Lahan Gambut di Indonesia (https://www.google.com/search)
Daerah Bereng Bengkel merupakan salah satu daerah yang juga mengalami kebakaran lahan gambut, walaupun tidak seluas daerah Tumbang Nusa, Kabupaten Pulang Pisau. Daerah Bereng Bengkel ini, mayoritas dihuni oleh para petani yang berasal dari pulau Jawa dan untuk membuka lahan berkebun, biasanya mereka lakukan dengan membakar lahan. Hal inilah yang menjadi salah satu penyebab terjadinya kebakaran lahan yang meluas apabila tidak diawasi secara langsung. Selain karena pembukaan lahan pertanian atau perkebunan, faktor alam seperti pepohonan yang mengering, hembusan angin yang kuat, serta kelalaian manusia dengan membuang puntung rokok sembarangan ke kawasan hutan yang mengering menjadi penyebab terjadinya kebakaran lahan baik itu berupa lahan gambut atau lahan rawa biasa. Untuk lahan gambut, walaupun api yang membakar pepohonan dan rerumputan sudah padam, akan tetapi jauh dibawah permukaan tanah api masih membara, seperti yang dikutip pada http://www.dw.com, Menteri Lingkungan Hidup dan Kehutanan (LHK) Siti Nurbaya Bakar membenarkan, kebakaran sulit dipadamkan karena baik di Kalimantan maupun Sumatera, titik api berada pada kedalaman tiga sampai lima meter di bawah tanah. Inilah karakteristik tanah gambut, jika sudah terbakar.

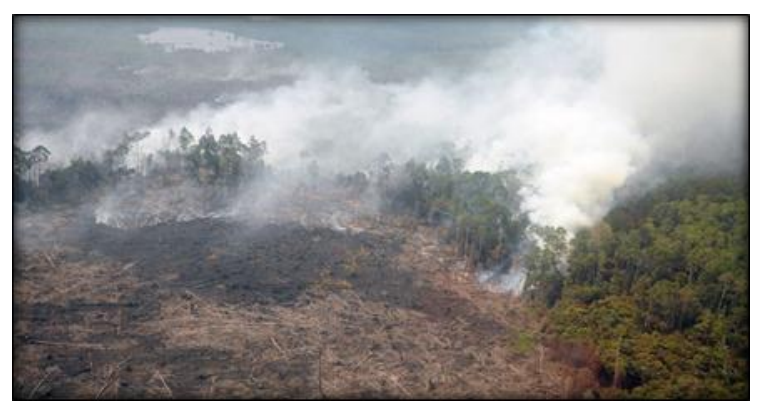

Gambar 3. Kebakaran Lahan Gambut (https://www.google.com/search) 


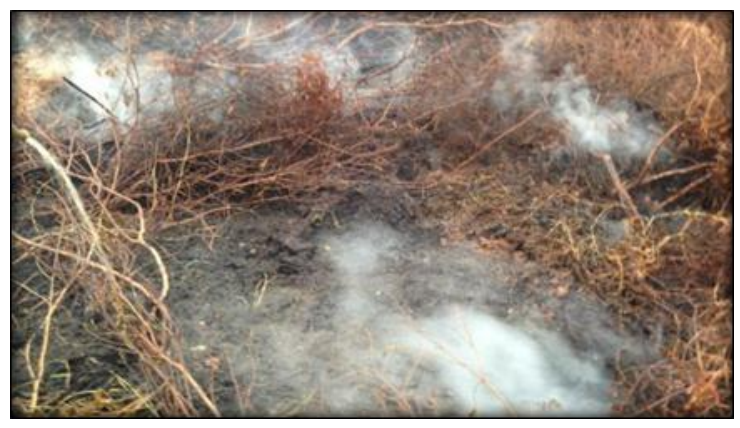

Gambar 4. Kebakaran tanah gambut dibawah permukaan tanah (https://www.google.com/search)

Didorong untuk memberikan informasi kepada masyarakat tentang penyebab, cara pencegahan serta penanggulangan kebakaran lahan gambut, maka pengabdian kepada masyarakat mengenai Sosialisasi pencegahan kebakaran di lahan gambut di daerah Bereng Bengkel Kota Palangka Raya ini dilaksanakan.

\section{METODE PELAKSANAAN}

Pengabdian kepada masyarakat mengenai Sosialisasi pencegahan kebakaran di lahan gambut di daerah Bereng Bengkel Kota Palangka Raya ini dilaksanakan pada hari Rabu,

Februari 2016 bertempat disalah satu kediaman anggota kelompok tani di kelurahan Bereng Bengkel.

Sasaran pengabdian kepada masyarakat ini adalah ibu-ibu kelompok tani yang berada di kelurahan Bereng Bengkel. Metode pengabdian ini dilaksanakan dengan cara sosialisasi yaitu dengan pemaparan materi dari perwakilan Badan Penanggulangan Bencana Daerah (BPBD) Provinsi Kalimantan Tengah Bapak Japalmen Rajagukguk, ST. dan Tim Dosen yang terdiri dari Novrianti, Nirwana
Puspasari, dan Noviyanthy Handayani, dan dilanjutkan dengan sesi tanya jawab.

\section{HASIL DAN PEMBAHASAN}

\section{Kegiatan kepada masyarakat} mengenai Sosialisasi Pencegahan kebakaran di lahan gambut di daerah Bereng Bengkel Kota Palangka Raya ini dilaksanakan oleh Tim Dosen dari program studi Teknik Sipil Universitas Muhammadiyah (UMP) didampingi oleh Badan Penanggulangan Bencana Daerah (BPBD) provinsi Kalimantan Tengah. Hal ini dikarenakan BPBD mempunyai data-data yang akurat serta konsep pencegahan kebakaran lahan sesuai dengan instruksi dan arahan dari Presiden Republik Indonesia, Joko Widodo.

Menurut data BPBD provinsi Kalimantan Tengah tahun 2015, luas kawasan terbakar 14.843,3 Ha (Ops. Darat) sedangkan menurut Citra Satelit adalah 402.779 Ha dengan jumlah total hotspot (titik api) berdasarkan satelit NOAA-18 sebanyak 4.292 titik. Meluasnya kebakaran lahan gambut ini memicu terjadinya kabut asap yang sangat parah, sehingga cahaya matahari pun sukar menembusnya dan membuat buruk kualitas udara yang mengakibatkan diliburkannya anak-anak sekolah, berkurangnya jam kerja perkantoran, dan matinya sejumlah tanaman para petani. Taksiran kerugian diperkirakan dari sektor pertanian 9,3 M, perdagangan hotel, dan restoran dengan kerugian 2,07 $\mathrm{M}$, dan sektor angkutan dan komunikasi (Agst-Sept) 24,31 M. Sedangkan dalam bidang kesehatan jumlah penderita Ispa se-Kalimantan Tengah 67.582 orang bahkan di beberapa daerah ada bayi yang meninggal karena buruknya kandungan udara yang dihirup. Selain itu, juga diberlakukan Masa Siaga Darurat s/d 
Tanggap Darurat Bencana 148 Hari mulai tanggal 26 Juni sampai 20 Nopember 2015.

Rangkaian kegiatan yang sudah dilakukan selama Penanganan Kebakaran Hutan dan Lahan antara lain:

1. Pra Bencana (rapat koordinasi, sosialisasi, dan pengembangan desa tangguh bencana).

2. Masa Darurat (pembentukan dan pengaktifan posko, penyaluran dan pendistribusian logistik, penanganan penderita ISPA)

3. Pasca Bencana (pemulihan (Rehabilitasi dan Rekonstruksi) kawasan/daerah terdampak bencana).

Salah satu kinerja dari BPBD provinsi Kalimantan Tengah tahun 2016 adalah mengenai konsep pencegahan kebakaran hutan dan lahan adalah dengan pemberdayaan masyarakat desa. Adapun konsep pencegahannya, yaitu :

1. Menyebarkan peringatan dini melalui media lokal (cetak, radio), agar diketahui oleh kelompok masyarakat, akan terjadinya kemarau panjang yang berpotensi menyebabkan kebakaran;

2. Memantau aktivitas di sekitar lahan, terutama daerah rawan kebakaran melalui patroli harian;

3. Menyebarluaskan informasi larangan melakukan pembakaran;

4. Persiapan, pelatihan dan penyegaran untuk semua petugas terkait dan masyarakat dalam usaha-usaha pemadaman kebakaran;

5. Rencanakan penanggulangan bersama dengan masyarakat, LSM, dan perusahaan-perusahaan di sekitar hutan;
6. Pastikan ketersediaan peralatan pemadaman dan semua peralatan berfungsi dengan baik;

7. Melakukan pengecekan sumbersumber air untuk rencana pemadaman;

8. Melakukan pertemuan dan komunikasi secara rutin antara masyarakat, perusahaan, LSM dan petugas pemadam kebakaran;

9. Melakukan pemadaman sedini mungkin jika ditemui sumber api meskipun kecil.

Kegiatan sosialisasi ini memberikan tambahan informasi kepada masyarakat daerah Bereng Bengkel mengenai penyebab dan pencegahan kebakaran lahan dan hutan khususnya didaerah yang memiliki jenis tanah gambut. Dan diharapkan kedepannya ada peran serta masyarakat dalam menangani kebakaran lahan dan hutan yang berada di lingkungan sekitarnya.

Berikut ini beberapa dokumentasi pada saat kegiatan pengabdian kepada masyarakat mengenai "Sosialisasi pencegahan kebakaran lahan gambut didaerah Bereng Bengkel Kota Palangka Raya".

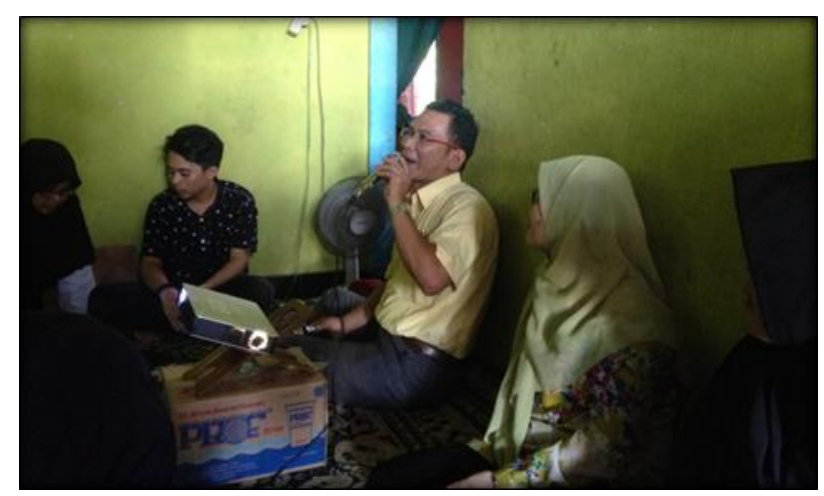

Gambar 5. Sesi paparan materi dari narasumber BPBD Prov. Kalteng 


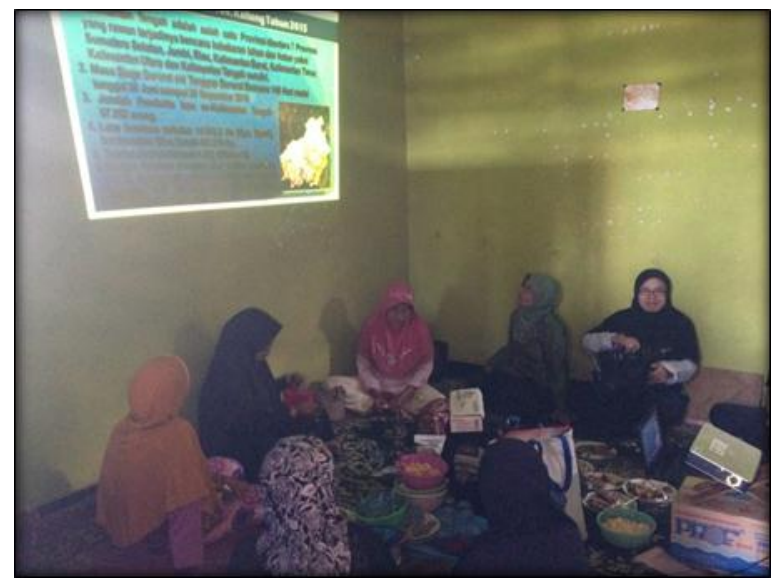

Gambar 6. Suasana pada saat pemaparan materi

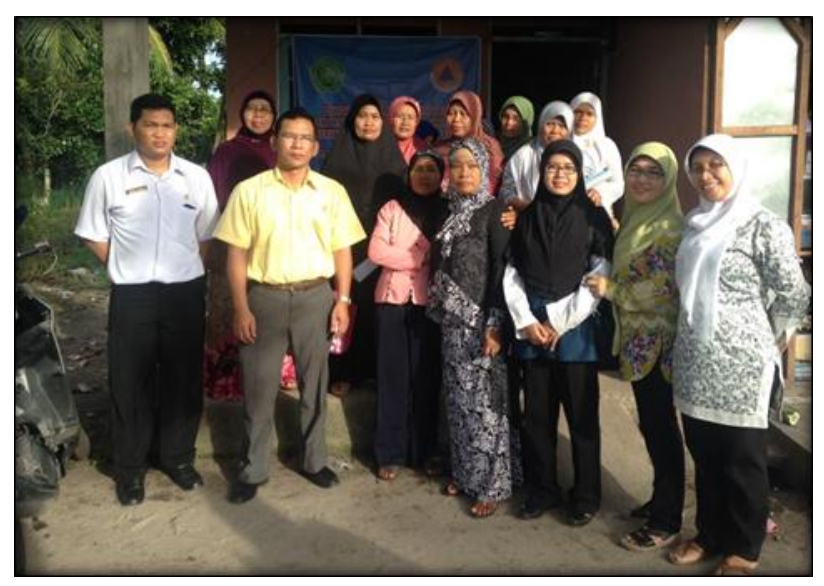

Gambar 7. Berfoto bersama Narasumber, Tim Dosen Pengabdian Masyarakat dan Masyarakat sasaran

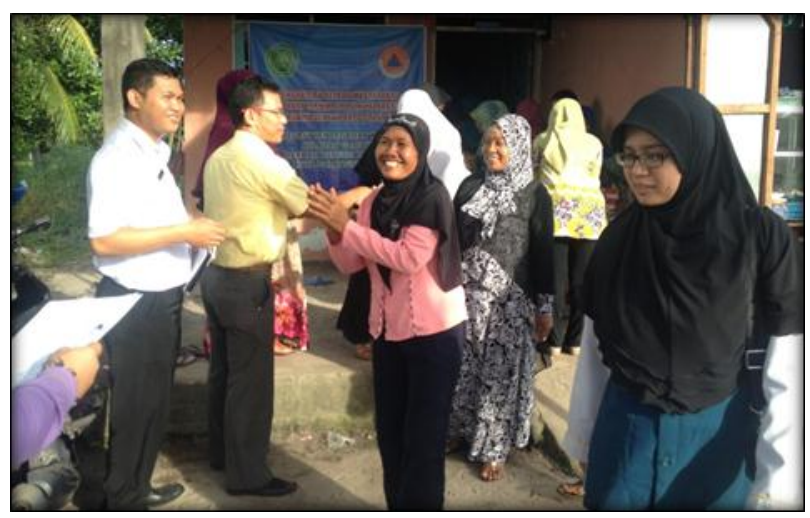

Gambar 8. Suasana keakraban saat berakhirnya kegiatan

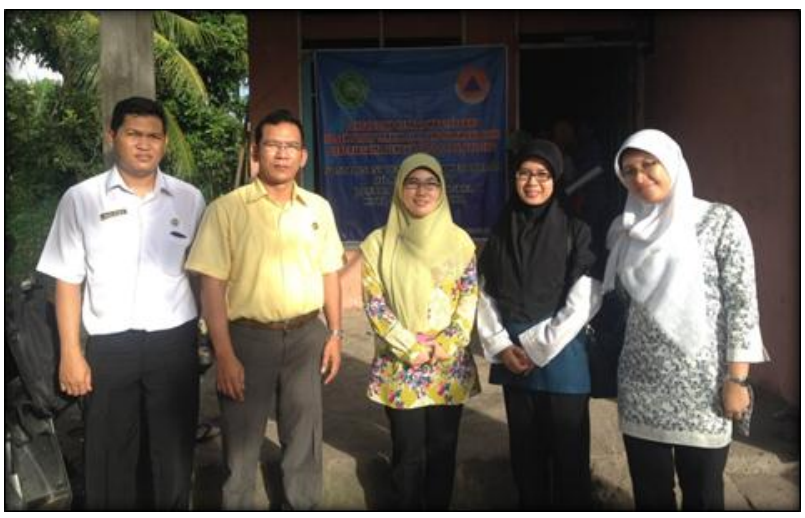

Gambar 9. Narasumber BPBD Prov. Kalteng dan Tim Dosen Pengabdian Masyarakat

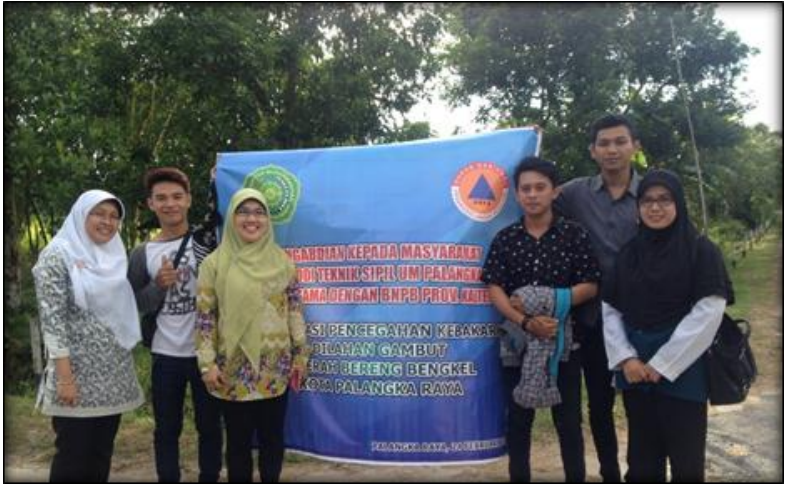

Gambar 10. Tim Dosen Pengabdian Masyarakat dan mahasiswa pendamping

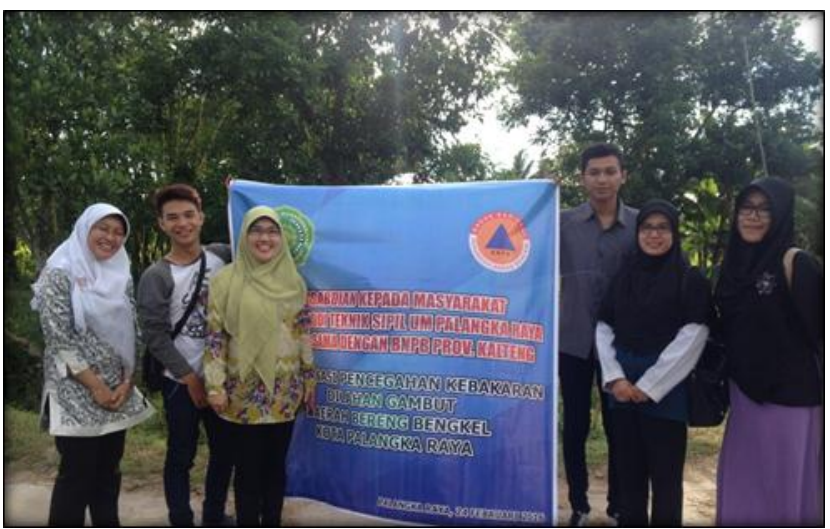

Gambar 11. Tim Dosen Pengabdian Masyarakat dan mahasiswa pendamping 


\section{KESIMPULAN}

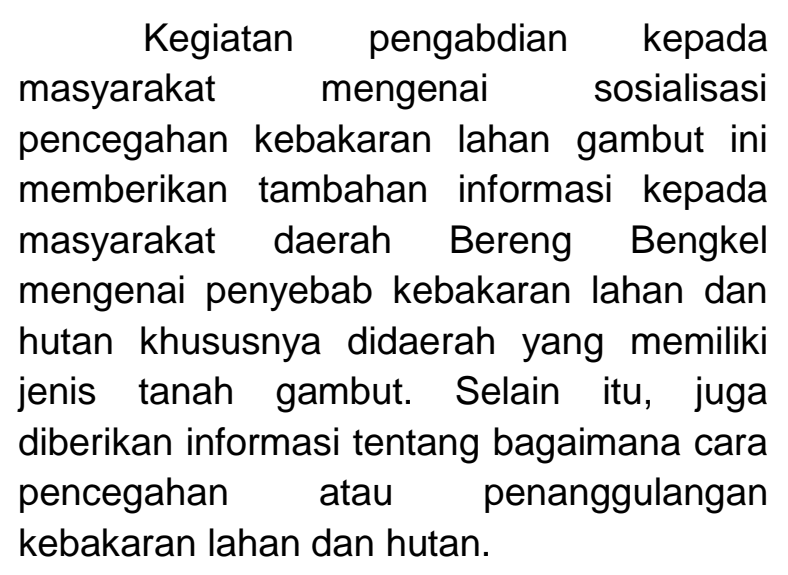

\section{SARAN}

Saran untuk kegiatan pengabdian masyarakat selanjutnya adalah sebagai berikut:

1. Kegiatan sosialisasi seperti ini hendaknya diadakan lagi pada waktu malam hari, sehingga bapak-bapak dari kelompok tani bisa ikut berpartisipasi.

2. Sosialisasi hendaknya juga melibatkan para pemangku jabatan seperti ketua RT, Ketua RW, Lurah ataupun Camat di daerah Bereng Bengkel dan sekitar, sehingga konsep pencegahan kebakaran dengan pemberdayaan masyarakat dapat tercapai.

3. Perlunya sosialisasi lanjutan mengenai "Pelatihan Penanggulangan Kebakaran Lahan". dan juga pelatihan dan perekrutan relawan desa.
Gambut/tabid/2838/language/id-

ID/Default.aspx diakses tanggal 2 Maret 2016.

Pemprov Kalimantan Tengah. ... .

Manajemen Pemanfaatan Lahan Gambut Secara Bijaksana dan Berkelanjutan

http://kalteng.go.id/indo/Gambut.htm diakses tanggal 2 Maret 2016.

Rajagukguk, Japalmen. 2016. Pencegahan Kebakaran Hutan Dan Lahan Dengan Pemberdayaan Masyarakat Desa. Palangka Raya. Badan Penanggulangan Bencana Daerah Prov. Kalteng.

Welle, Deutsche. 2015. Penyebab

Kebakaran Hutan Terungkap

http://www.dw.com/id/penyebab-kebakaranhutan-terungkap/a-18801135 diakses tanggal 2 Maret 2016.

Wikipedia. 2016. Gambut.

https://id.wikipedia.org/wiki/Gambut diakses tanggal 2 Maret 2016.

Wihardandi, Aji. 2013. Lahan Gambut Indonesia, Bom Waktu Emisi Karbon Dunia.

http://www.mongabay.co.id/2013/09/30/laha n-gambut-indonesia-bom-waktu-emisikarbon-dunia/ diakses tanggal 2 Maret 2016.

\section{DAFTAR PUSTAKA}

Google. ... Lahan Gambut di Indonesia. https://www.google.com/search diakses tanggal 2 Maret 2016.

Indonesia, Wetlands International. 2009.

\section{Gambut.}

http://indonesia.wetlands.org/Kegiatankami/ 